Original Research Paper

\title{
Pengembangan Ekonomi Pelaku Usaha Rumah Tangga di Desa Rempung Lombok Timur
}

\author{
Hailuddin $^{1 *}$, Mukmin Suryatni ${ }^{1}$, Irwan Suriadi ${ }^{1}$, Endang Astuti ${ }^{1}$ \\ ${ }^{\text {I}}$ Fakultas Ekonomi dan Bisnis, Universitas Mataram, Mataram, Indonesia
}

https://doi.org/10.29303/jpmpi.v3i2.617

Sitasi: Hailuddin., Suryatni, M., Suriadi, I., \& Astuti, E., (2021). Pengembangan Ekonomi Pelaku Usaha Rumah Tangga di Desa Rempung Lombok Timur. Jurnal Pengabdian Magister Pendidikan IPA, 4(1)

\section{Article history}

Received: 05 Desember 2020

Revised: 30 Desember 2020

Accepted: 05 Februari 2021

*Corresponding Author: Hailuddin, Fakultas Ekonomi dan Bisnis, Universitas Mataram, Mataram, Indonesia; Email: didin@unram.ac.id

\begin{abstract}
Pengembangan ekonomi khususnya untuk usaha rumah tangga dimaksudkan untuk penggalian potensi-potensi kemandirian dan pengembangan ekonomi masyarakat melalui pemberdayaan dan pengembangan ekonomi dalam pengelolaan sumber daya potensial secara berkelanjutan. Terkait dengan hal itu, pembinaan ini bertujuan untuk memberikan motivasi, pengetahuan dan tehnik dalam mengelola dan mengembangkan usaha yang dijalani, baik secara individu maupun berkelompok bagi masyarakat. Dengan berlandaskan pada subtansi yang dimaknai bahwa penataan dan pengembangan usaha rumahan ini berlandaskan pada ketersediaan sarana produksi lokal, pengolahan dan penataan output yang dikendalikan oleh masyarakat secara mandiri dan berkesinambungan. Subyek dari kegiatan ini adalah kelompok maupun individu para pelaku usaha rumahan di Desa Rempung Lombok Timur. Pelaksanaan kegiatan penyuluhan ini menggunakan metode diskusi, ceramah dan ramah tamah. Hasil dari kegiatan ini adalah banyaknya hal yang diungkapkan oleh peserta dalam memulai usaha, seperti bagaimana membangun usaha, apa persiapannya, bagaimana dengan permodalan, pemasarannya kemana dan lain-lain. Karena itu tim mengajak mereka dulu untuk membangun kemitraan usaha bersama untuk menampung permasalahan usaha yang mereka tekuni. Selanjutnya dipaparkan tentang bagaimana menekuni suatu usaha dan dilanjutkan dengan penjelasan tentang pengetahuan manajemen usaha. Ahirnya harapan tim penyuluh, mereka bisa melakukan usaha dengan pemahaman perencanaan usaha serta motivasi untuk membangun dan menekuni usaha mereka dengan baik agar bisa berkembang.
\end{abstract}

Keywords: Usaha rumahan; Usaha bersama; Pemberdayaan; Manajemen usaha.

pada kelompok usaha kecil pada lapisan masyarakat bawah.

Usaha skala kecil yang bersifat rumahan merupakan salah satu usaha yang dapat menciptakan lapangan kerja baru dan sebagai penunjang pembangunan ekonomi yang erat kaitannya dengan ekonomi nasional. Usaha ini mempunyai kedudukan, potensi dan peranan yang sangat penting dalam mewujudkan tujuan pembangunan ekonomi (Bratakusumah \& Solihin, 2004). Keberadaan usaha skala kecil ini mampu 
memperluas kesempatan kerja, distribusi pendapatan yang lebih merata dan dapat pula meningkatkan pendapatan masyarakat yang sekaligus mampu menciptakan stabilitas ekonomi.

Pembinaan dan pengembangan usaha skala kecil khususnya usaha dibidang jasa, perdagangan dan usaha kreatif lainnya telah lama mendapat perhatian pemerintah dan swasta. Bentuk perhatian diwujudkan dalam upaya pembinaan dan pengembangan seperti penyuluhan, pendidikan/pelatihan, monitoring, konsultasi, studi banding serta dalam bentuk lainnya yang mengarah pada perbaikan mutu usaha (Mardiasmo, 2002).

Di tingkat daerah khususnya di Lombok Timur, jenis usaha skala kecil ini cukup banyak dan beraneka ragam bentuknya yang tersebar merata baik di daerah perkotaan maupun perdesaan. Keterlibatan masyarakat cukup banyak di dalamnya dan bahkan sebagian besar diantaranya menjadi sumber mata pencaharian utama. Oleh karena itu, pembinaan dan penyuluhan tetap harus dilaksanakan meskipun belum merata secara keseluruhan, sebagaimana halnya yang dilakukan selama ini.

Salah satu bentuk usaha yang cukup dominan adalah usaha perdagangan khususnya dagang kecil dan peternakan yang merupakan jenis usaha yang mempunyai skala usaha yang sangat terbatas sumber dayanya. Meskipun memiliki kemampuan dalam menciptakan atau menyerap lapangan kerja khususnya dari kalangan keluarga sendiri, keberadaan para pelaku usaha ini memiliki potensi besar khususnya di daerah pedesaan. Dengan demikian diharapkan akan mampu meningkatkan pendapatan keluarga masyarakat umumnya yang pada akhirnya akan berkontribusi secara regional maupun nasional (Halim, 2001).

Oleh karena itu usaha-usaha pemberdayaan kelompok ini dirasa sangat penting untuk dilakukan oleh semua pihak terutama pemerintah daerah dengan penataan yang baik, pembinaan yang berkesinambungan, memperkuat aspek permodalan dan lain-lain, sehingga peran dalam penyerapan tenaga kerja dan berkontribusi dalam meningkatkan penghasilan pelaku usaha yang pada gilirannya akan meningkatkan kesejahteraan keluarga makin nyata dirasakan.

Banyak faktor yang menentukan
kemampuam dalam memulai untuk
mengembangkan usaha skala kecil yang merupakan
sektor informal ini. Tetapi dalam penyuluhan dan pembinaan kali ini perhatian utama diarahkan pada faktor-faktor yang mendukung pengembangan dan pemberdayaan usaha rumah tangga pedagang kecil dan pengembangan usaha yang sudah eksis (Kuncoro, 2004). Semua ini pada akhirnya ditujukan untuk dapat meningkatkan keterampilan dan kemampuan pelaku usaha dalam pengelolaan dan pengembangan usahanya. Karenanya diharapkan dari penyuluhan dan pembinaan ini adalah adanya peningkatan kemampuan pemberdayaan usaha, penataan lingkungan usaha yang nyaman, aman dan kemampuan serta keterampilan dalam mengembangkan usahanya khususnya para pelaku usaha rumahan skala kecil.

Para pelaku usaha rumahan ini seringkali menghadapi masalah/kendala terutama yang berkaitan dengan aspek keuangan atau pengelolaan modal, pemasaran dan lainnya. Permasalahan yang timbul sering terlambat diantisipasi oleh para pengusaha kelompok ini yang berbentuk usaha berskala kecil. Hal demikian disebabkan terlambat mengetahui adanya permasalahan itu sendiri sehingga tanpa disadari telah berkembang menjadi problem yang kompleks. Kenyataan ini merupakan fenomena yang unik karena para pengusaha yang mempunyai sifat tradisional, tidak melihat hal itu sebagai suatu kendala. Beberapa permasalahan yang merupakan sumber dari sebab terjadinya kegagalan usaha atau sulit berkembang sebagai akibat pada pola pekerjaan yang sangat sederhana dan tradisional. Hal lain yang kurang mendukung kemajuan usaha kelompok ini adalah karena keterbatasan pengetahuan, pengalaman yang terbatas serta motivasi yang masih kurang.

Kelompok sasaran dalam penyuluhan dan pembinaan ini adalah para pelaku usaha rumahan dan pengusaha/dagang kecil khususnya yang ada di Karang Baru Desa Rempung Lombok Timur. Dalam penyuluhan dan pembinaan ini khalayak sasaran strategis yang dilibatkan adalah koordinator pedagang, para pelaku usaha, dan pemuda serta aparat lingkungan setempat. Dengan kegiatan penyuluhan ini diharapkan hasilnya akan mampu diperluas kepada masyarakat lainnya yang memiliki bakat dan keinginan untuk berusaha dan menghadapi permasalahan yang sama.

\section{Metode}

Materi yang disampaikan dalam penyuluhan dan pembinaan ini meliputi teknik 
memulai usaha, pengelolaan usaha, pemasaran, menejemen usaha dan kiat pengembangan usaha dan pemanfaatan waktu luang. Penyuluhan dan pembinaan ini disampaikan melalui metode ceramah, dan setelah ceramah berakhir dilanjutkan dengan diskusi/tanya jawab dengan memberikan petunjuk atas kesulitan dan permasalahan yang dihadapi untuk dipecahkan bersama.

Kegiatan ini dilaksanakan melalui tahapan sebagai berikut:

\section{Realisasi Pemecahan Masalah}

Kegiatan pengabdian dan penyuluhan ini telah dilaksanakan pada September 2017 bertempat di Dusun Karang Baru Rempung Lombok Timur. Guna membantu memecahkan permasalahan yang di hadapi oleh para peserta, maka kerangka pemecahan masalah dalam hal ini mengajak mereka agar masuk atau membangun kebersamaan/kemitraan usaha yang dapat menampung dan memecahkan permasalahan yang dihadapi. Disamping itu diberikan pengetahuan tentang tehnik memulai usaha baru, mengelola/manajemen usaha, kegiatan produksi dan lainnya. Oleh karena itu melalui penyuluhan ini diharapkan mereka mengerti dan mampu memulai usahanya, melakukan perencanaan usaha dan pengelolaan usaha, cara pembukuan sederhana, sehingga mereka termotivasi untuk berusaha dengan tekun dan dapat mengelola usahanya dengan baik, agar dapat lebih berkembang.

\section{Khalayak Sasaran antara yang strategis}

Kelompok sasaran dalam penyuluhan dan pembinaan ini adalah para pelaku usaha rumahan, pelaku usaha existing (pemilik usaha) yang merupakan warga Karang Baru Rempung Lombok Timur. Dalam penyuluhan dan pembinaan ini khalayak sasaran yang strategis sering dilibatkan dalam kegiatan ini adalah aparat Dusun, karang taruna (remaja) serta ibu rumah tangga peminat usaha dan pelaku usaha. Dengan demikian hasil dari kegiatan yang dilakukan diharapkan dapat diperluas kepada masyaralat lainnya yang berkeinginan untuk berusaha dan menghadapi permasalahan yang sama.

\section{Metode yang Digunakan}

Materi yang disampaikan dalam penyuluhan dan pembinaan ini meliputi teknik memulai usaha, pengelolaan usaha, pemasaran, menejemen usaha dan kiat pengembangan usaha dengan pemanfaatan waktu luang. Penyuluhan dan pembinaan ini disampaikan melalui metode ceramah, dan setelah ceramah berakhir dilanjutkan diskusi dengan memberikan petunjuk atas kesulitan dari permasalahan yang dihadapi untuk dipecahkan bersama. Selanjutnya dilanjutkan dengan pendampingan/konsultasi langsung maupun melalui terlepon seluler.

\section{Hasil dan Pembahasan}

Dari kegiatan pengabdian masyarakat ini, para peserta mendapat pengetahuan yang mendasar dalam hal bagaimana memulai suatu usaha, dan cara mengelola/manajemen usaha yang terencana, yang meliputi :

1. Tahap kegiatan memulai suatu usaha; bagaimana menentukan pilihan suatu bidang usaha, serta persiapan awal yang perlu dilakukan.

2. Pengelolaan usaha barang hasil perdagangan: bagaimana cara mengelola usahanya sehingga tujuan itu sendiri dapat tercapai yaitu untuk meningkatkan kesejahteraan para pedagang pada khususnya dan masyarakat pada umumnya.

3. Manfaat dan pentingnya kemitraan dalam usaha: Manfaat apa yang bisa diperoleh pedagang dan masyarakat umum dengan adanya jalinan usaha serta menjelaskan pentingnya kerjasama atau bermitra, bagi kesejahteraan pelaku usaha khususnya dan masyarakat pada umumnya.

4. Mengelola/manajemen usaha, terutama masalah pembukuan usaha, prinsip dan penyuluhan keuangan dan pengelolaan modal.

Metode dan isi materi yang disampaikan disamping mendapat sambutan baik dari para peserta penyuluhan, juga mencerminkan kebutuhan mereka dalam beraktifitas untuk meningkatkan diri dalam melaksanakan kegiatan untuk memulai suatu usaha atau yang sedang ditekuninya, baik sebagai produsen maupun sebagi pedagang. Semangat dan keseriusan Tim Penyuluh dalam melaksanakan kegiatan ini juga merupakan modal utama (sebagai faktor pendorong) untuk bergerak memulai usaha dan mengatasi keterbatasan pengetahuan dan ketrampilan usaha, sekalipun belum sepenuhnya teratasi.

Kendala yang masih perlu perhatian adalah terbatasnya anggaran yang tersedia untuk 
melaksanakan kegiatan pengabdian pada masyarakat secara berkelanjutan. Hal ini menjadi salah satu faktor penghambat, sehingga tidak dapat memberi kemungkinan tambahan jadwal yang sebenarnya diperlukan. Efek lain yang ditimbulkan adalah terbatasnya jumlah peserta yang dapat mengikuti penyuluhan semacam ini. Untuk itu demi luasnya efek dari kegiatan ini, perlu ada upaya lanjutan kegiatan penyuluhan dengan jumlah peserta yang lebih besar.

\section{Kesimpulan}

Dengan selesainya kegiatan pengabdian masyarakat ini, dapat disimpulkan bahwa dengan membangun kegiatan usaha bersama/kemitraan dalam usaha, hasilnya dapat menyalurkan barang hasil usahanya secara bersama pula. Disamping pula adanya upaya saling membantu dalam permodalan serta tukar-menukar informasi dalam kegiatan produksi, sehingga dapat memperlancar usahanya mereka. Selain itu para peserta mengetahui besarnya manfaat dan pengetahuan dalam kemitraan usaha atau berkelompok dalam menjalankan usahanya. Adanya kerja sama antar kelompok/mitra usaha dapat mengatasi permasalahan yang dihadapinya secara bersama pula. Secara umum para peserta masih sangat kurang pengetahuan tentang tata cara memulai usaha, perencanaan usaha, dan mengelola/manajemen usaha yang baik. Oleh karena itu, dengan adanya kegiatan penyuluhan ini cukup membantu mereka untuk menambah wawasan dan pengetahuan, sehingga lebih mampu memacu mereka dalam menekuni suatu bidang usaha.

\section{Daftar Pustaka}

Bana, M, Yahya, 2002, Analisis Sistem Pengelolaan Keuangan daerah Kabupaten Alor Propinsi Nusa Tenggara Timur, Fakultas Ekonomi, UGM, Yogyakarta.

Bratakusumah, DS dan Solihin Dadang, 2004, Otonomi Penyelenggraan Pemerintahan Daerah, PT Gramedia, Jakarta.

Halim, Abdul, 2001, Manajemen Keuangan Daerah, UPP AMP YKPN, Yogyakarta.

Kuncoro, Mudrajad, 2004, Otonomi \& Pembangunan Daerah Reformasi,
Perencanaan, Strategi dan Peluang, Penerbit Erlangga, Jakarta.

Labni, 2005, Analisis Perbandingan Pemeringkatan Kemampuan Keuangan Daerah pada Pemerintah Daerah Se-Pulau Sumbawa, Mataram.

Mardiasmo, 2002, Otonomi dan Manajemen Keuangan Daerah, Andi Offset, Yogyakarta.

Robinson B. Richard dan Pearce A. John, 1997, Manajemen Strategik; Formulasi, Implementasi dan Pengendalian Jilid I, Binarupa Aksara, Jakarta.

Sumardi. 1986. Pembangunan dan Kemiskinan. Bulan Bintang. Rajawali Jakarta

Suseno Triyanto, WHg. 1990. Pembangunan Ekonomi. Kanisius. Yogyakarta 